\title{
The Influence of Communication, Team Work, and Organizational Commitment on Improving Employee Performance at PT Seroja Lukindo Lestari Surabaya
}

\author{
Cahya Dewi Anisah ${ }^{1}$, I Putu Artaya, SE, MM² \\ Narotama University \\ cahyadewi1710@gmail.com
}

\begin{abstract}
The purpose of this research is to determine the relationship between communication, team work, and organizational commitment to the performance of employees at PT Seroja Lukindo Lestari Surabaya. This research is using quantitative method. The population and sample based on questionnaires to employees of PT Seroja Lukindo Lestari Surabaya of 67 respondents. The method of data collection uses interviews, observations and questionnaires. Analysis of the data used validity test, reliability test, classic assumption test and multiple linear analysis test. The results of the research showed Communication (X1), Team Work (X2), and Organizational Commitment (X3) had a significant relationship to employee performance (Y) which have a significant value $<0.05$.
\end{abstract}

Keywords: Communication, Team Work, Organizational Commitment, Employee Performance

\section{INTRODUCTION}

The production process at PT. Seroja Lukindo Lestari Surabaya runs every day relying on every employee in each division to perform tasks in accordance with the procedures and responsibilities given to each employee. Employee performance according to (Sentngono, 2014: 179) is the work that can be achieved by a person or group of people in an organization, in accordance with the authority and responsibilities of each - in order to achieve organizational goals. Phenomena that occur at PT Surabaya Lukindo Lestari Seroja is lack of communication or slow delivery in each division which results in the hampered employee performance process, according to (Karlfried Knapp, 2009: 6) Communication is an interpersonal interaction that uses a system of linguistic symbols, such as verbal symbol systems (words) and nonverbal. In addition, the lack of communication also has an impact on team work between divisions, (Bachtiar, 2004: 7) the definition of team work is the synergy of the strength of several people in achieving a desired goal together. Another important factor in achieving targets in the company is those who are able to develop and keep their employees to survive, commit and be able to work as expected. In other cases it was found that there were many employees who were often late, hanging out at work, the number of employees coming in and out, causing the target companies to move more slowly tending to decline in production results, employees like this could lack commitment to employees, (Luthans, 2006) organization commitment is a strong desire to remain as a member of a particular organization, the desire to strive in accordance with the wishes of the organization, as well as certain beliefs and acceptance of values and goals of the organization.

In an effort to improve the performance of employees it is necessary to conduct communication between the board of directors and divisions so that employee performance does not weaken and the production process of the company runs smoothly according to the objectives of the company so that the target of the company is achieved and the company can compete in this increasingly fierce business competition. Not only communication, team work factor also needs to be taken care of so that the work process can run smoothly and the organization in the company feels harmonious, commitment to the organization in the company must also be maintained so that misdirection occurs and employees feel appreciated by the company so employees feel at home and always perform satisfying performance, if all three are carried out by the company then it allows the company to dominate the existing market.

Based on the formulation of the problem above, the purpose of the research to be carried out are to find out the effect of the Communication variable on Employee Performance, to find out the effect of variable Team Work on Employee Performance, to find out the effect of the Organizational Commitment variable on Employee Performance, to find out the simultaneous effect of Communication variables, Team Work and Organizational Commitment on Employee Performance at PT. Seroja Lukindo Lestari Surabaya. 


\section{THEORETICAL FRAMEWORK}

\subsection{Human Resources Management}

(Bohlander and Snell, 2010: 4) human resource management (HRM) is a science that studies how to empower employees in a company, make work, work groups, develop employees who have the ability, identify an approach to develop employee performance and provide benefits to them for their work.

\subsection{Communication}

(Muhammad, 2011: 1) Communication is a basic human activity. By communicating, humans can interact with each other both in daily life in the household, at work, in the marketplace, in society or wherever humans are.

No human will not be involved in communication.

\subsection{Team Works}

(Dewi, 2007: 152) defining team work (teamwork) is a form of work in a group that must be organized and managed properly. The team consists of people who have different skills and are coordinated to work with the leadership. There is strong interdependence with each other to achieve a goal or complete a task.

\subsection{Organizational Commitment}

Organizational commitment is a situation where an employee sided with a particular organization and its goals and desires to keep membership in the organization. So high job involvement means taking sides with a particular individual's work, while high organizational commitment means taking sides with the organization that recruits the individual (Robbins, 2008).

\subsection{Employee Performance}

(Hasibuan, 2003: 93) is a result of work achieved by someone in carrying out the tasks assigned to him based on skills, experience, sincerity and time. In other words, performance is the result of work achieved by someone in carrying out the tasks assigned to him according to the criteria set and according to (Sentngono, 2014: 179) performance is the work that can be achieved by a person or group of people in an organization, in accordance with their authority and responsibilities of each in order to achieve organizational goals.

\subsection{Previous Research}

(Amanda Carolina Lakoy, 2015) The results of the study showed that communication, group collaboration and creativity simultaneously had a significant effect on employee performance at Aryaduta Manado Hotel. This shows that the management of Aryaduta Manado Hotel must pay attention to the factors of communication and group collaboration to encourage higher employee performance. (Mustafa Zincirkiran, Abdurrahim Emhan and Mehmet Fatih Yasar,2015) Results: Demonstrate that team work has affected 23.5\% of employee performance while the remaining 76.5 other factors that affect employee performance were not examined in this study. (Salim Musabah Bakhit Al Zefeiti dan Noor Azmi Mohammad ,2017) The empirical results indicate that all organizational commitment subscales (affective, normative, and continuance) have a significant impact on work performance dimensions, contextual and task performance.

\section{RESEARCH METHOD}

\subsection{Type of Research}

The approach used in this study is a quantitative approach. According to (Sugiyono, 2016: 35-36) quantitative methods can be interpreted as research methods based on the philosophy of positivism, used to examine certain populations or samples, data collection using research instruments, data analysis quantitative statistical nature in order to test the predetermined hypothesis.

\subsection{Place and Time of Research}

This research was conducted at PT. Seroja Lukindo Lestari Surabaya address J1. Kalianak 55 A1 Surabaya. The time of the study is from September 2018 - January 2019.

\subsection{Conceptual Framework}

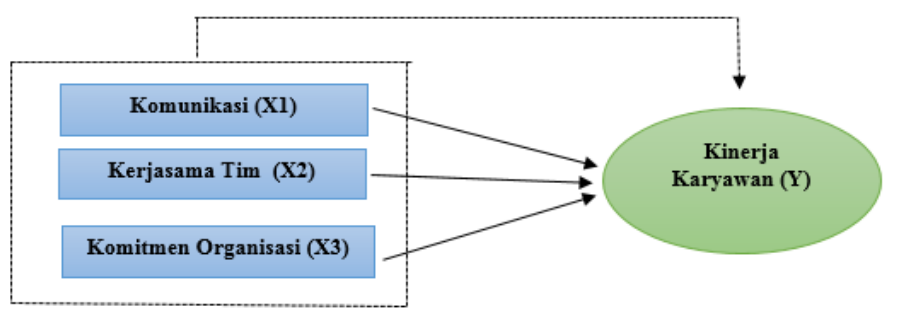




\subsection{Population and Sample}

The population in this study were all employees of PT. Seroja Lukindo Lestari Surabaya with a population of 200 employees. The purpose of the population is held in order to determine the size of the sample members taken from the sample members and limit the applicability of the generalization area (Sugiyono in Ruslan, 2010: 133) . Samples are part of the number and characteristics of the population. This study uses the Slovin formula which is used to calculate the sample size of a known population, based on the results of a sample of 67 responses.

\subsection{Data Collection Method}

This research uses a type of primary data, namely data obtained directly from the original source. Primary data is specifically collected to answer research questions. Primary data is usually obtained from field surveys that use all ordinal data collection methods (Sugiyono, 2010: 137). This data was obtained from the results of filling out a questionnaire regarding Communication, Team Work, and Organizational Commitment towards Employee Performance which was filled by employees of PT. Seroja Lukindo Lestari Surabaya.

\subsection{Operational Definition of Research Variable}

$\mathrm{X} 1$ : Communication. Communication is an interpersonal interaction that uses a system of linguistic symbols, such as a system of verbal symbols (words) and nonverbal by PT. Seroja Lukindo Lestari Surabaya.

X2: Team Work. Team Work is the synergy of the strength of several people in achieving a common goal for PT. Seroja Lukindo Lestari Surabaya.

X3: Organizational Commitment. Organizational Commitment is an attitude that reflects employee loyalty to PT. Seroja Lukindo Lestari Surabaya.

Y: Employee performance. Employee Performance is the result of work achieved by a person or group of people in PT. Seroja Lukindo Lestari Surabaya.

\subsection{Data Analysis Method}

\section{Validity and Reliability Test}

Validity test is used to measure the validity of a questionnaire (Imam Ghozali, 2013: 52). While reliability testing is used as a tool to measure a questionnaire which is an indicator of a variable or construct. A questionnaire is said to be reliable if someone's answer to the question is consistent or stable over time (Ghozali, 2013: 47) By using the SPSS 16 program for Windows. SPSS provides facilities to measure reliability with Cronbach Alpha $(\alpha)$ statistical tests. A variable is said to be reliable if it gives a value of $\alpha>0.60$

\section{Multiple Regression Analysis Model}

The method of this analysis used in this study is multiple regression models approach the return. This method has been chosen to measure Communication (X1), Team Work (X2), and Organizational Commitment (X3) to Employee performance (Y). The basic formula of multiple regression analysis takes the following form:

\begin{tabular}{|c|c|}
\hline & $Y=a+b 1 X 1+b 2 X 2+b 3 X 3+e$ \\
\hline $\mathrm{Y}$ & $=$ Performance \\
\hline A & $=$ Constants (price $\mathrm{Y}$, if $\mathrm{X}=0$ ) \\
\hline b1, b2, b3 & $\begin{array}{l}=\text { Regression coefficient (indicates the number of increase or } \mathrm{d} \\
\text { variable } \\
\text { based on the relationship of the value of the independent variable) }\end{array}$ \\
\hline $\mathrm{X} 1$ & $=$ Communication \\
\hline $\mathrm{X} 2$ & $=$ Team Work \\
\hline $\mathrm{X} 3$ & $=$ Organizational Commitment \\
\hline $\mathrm{e}$ & $=$ Error \\
\hline
\end{tabular}

\section{RESULT AND DISCUSSION}

\subsection{Reliability and Validity}

Based on research shows that the cronbanch alpha value is 0.894 which means that it is above the acceptance limit of 0.6 therefore, the research instrument for the relationship between variables shows good consistency and acceptable data. Based on the research value of the correlation index for the relationship between the independent variables (Communication, Team Work and Organizational Commitment) and the dependent variable (Employee Performance) greater than 0.3 and below the significant level of 5\% (0.05). Correlation 
between communication (0.727), team work (0.819) and organizational commitment (0.679) with employee performance (1.000) shows a positive relationship. Therefore, the data is considered valid.

\subsection{Multiple Linear Regression Result}

Table 1. Multiple Linear Regression Result

\begin{tabular}{|c|c|c|c|c|c|c|c|c|}
\hline \multicolumn{9}{|c|}{ Coefficients $^{\mathrm{a}}$} \\
\hline & & \multicolumn{2}{|c|}{$\begin{array}{l}\text { Unstandardized } \\
\text { Coefficients }\end{array}$} & \multirow{2}{*}{\begin{tabular}{|c|}
$\begin{array}{c}\text { Standardize } \\
\mathrm{d} \\
\text { Coefficients }\end{array}$ \\
Beta \\
\end{tabular}} & \multirow[b]{2}{*}{$\mathrm{t}$} & \multirow[b]{2}{*}{ Sig. } & \multicolumn{2}{|c|}{$\begin{array}{l}\text { Collinearity } \\
\text { Statistics }\end{array}$} \\
\hline \multicolumn{2}{|c|}{ Model } & B & Std. Error & & & & $\begin{array}{c}\text { Toleranc } \\
\mathrm{e}\end{array}$ & VIF \\
\hline \multirow[t]{4}{*}{1} & (Constant) & 2.218 & .447 & & 1.064 & .292 & & \\
\hline & ROMUNIKASI & .444 & .108 & .407 & 4.097 & .000 & .886 & 1.128 \\
\hline & KERJASAMATIM & .253 & .107 & .254 & 2.374 & .021 & .762 & 1.313 \\
\hline & $\begin{array}{l}\text { KOMITMENORG } \\
\text { ANISASI }\end{array}$ & .230 & .104 & .234 & 2.223 & .030 & .786 & 1.272 \\
\hline & $\begin{array}{l}\text { pendent Variable: } \\
\text { RJAKARYAWAI }\end{array}$ & & & & & & & \\
\hline
\end{tabular}

Source: SPSS Output, 2019.

Based on the analysis result shows that the equation of multiple regression model in this research is shown as follows:

Where :

$$
\mathrm{Y}=2.218+0.407 \mathrm{X} 1+0.254 \mathrm{X} 2+0.234 \mathrm{X} 3+\mathrm{e}
$$

$\mathrm{Y}=$ Employee Performance

$\mathrm{X} 1=$ Communication

$\mathrm{X} 2$ = Team Work

$\mathrm{X} 3$ = Organization Commitment

e $=$ Error

a. The constant $(\alpha)$ is 2.218 , this shows an influence on the relationship between the Communication variables (X1), Team Work (X2) and Organizational Commitment (X3) with employee performance (Y), meaning that if all independent variables are zero, then Employee (Y) is estimated to be 2.218.

b. If the others are constant, an increase of one pin in Communication (X1) will result in an average increase of at least 0.407 in Employee Performance (Y).

c. If the others are constant, increasing one pin in Team Work (X2) will result in an average increase of at least 0.254 in Employee Performance (Y).

d. If the others are constant, an increase of one pin in Organizational Commitment (X3) will result in an average increase of at least 0.234 in Employee Performance (Y).

\subsection{Result of R Square}

\begin{tabular}{|l|r|r|r|r|r|}
\hline \multicolumn{7}{|c|}{ Model Summarx } \\
\hline Model & $\mathrm{R}$ & R Square & Adjusted R Square & $\begin{array}{c}\text { Std. Error of the } \\
\text { Estimate }\end{array}$ & Durbin-Watson \\
\hline 1 & $.671^{\mathrm{a}}$ & .450 & .424 & .53043 & 2.065 \\
\hline
\end{tabular}

Table 2. Result of R Square

Source: SPSS Output, 2019

The value of $\mathrm{R}$ Square is 0.450 which means that all independent variables: Communication, Team Work, Organizational Commitment has a positive relationship with Employee Performance. 
4.4 Test of Classical Assumption 1. Multicollinearity Result
Tabel 3. Multicollinearity Result

\begin{tabular}{|c|c|c|c|c|c|c|c|c|}
\hline \multicolumn{9}{|c|}{ Coefficients $^{a}$} \\
\hline \multirow{2}{*}{\multicolumn{2}{|c|}{ Model }} & \multicolumn{2}{|c|}{$\begin{array}{l}\text { Unstandardized } \\
\text { Coefficients }\end{array}$} & \multirow{2}{*}{$\begin{array}{c}\text { Standardiz } \\
\text { ed } \\
\text { Coefficient } \\
\text { s } \\
\\
\\
\text { Beta } \\
\end{array}$} & \multirow[b]{2}{*}{$\mathrm{t}$} & \multirow[b]{2}{*}{ Sig. } & \multicolumn{2}{|c|}{$\begin{array}{l}\text { Collinearity } \\
\text { Statistics }\end{array}$} \\
\hline & & B & Std. Error & & & & ce & VIF \\
\hline \multirow[t]{4}{*}{1} & (Constant) & 2.218 & .447 & & 1.064 & .292 & & \\
\hline & KOMUNIKASI & .444 & .108 & .407 & 4.097 & .000 & .886 & 1.128 \\
\hline & KERJASAMATIM & .253 & .107 & .254 & 2.374 & .021 & .762 & 1.313 \\
\hline & $\begin{array}{l}\text { KOMITMENORG } \\
\text { ANISASI }\end{array}$ & .230 & .104 & .234 & 2.223 & .030 & .786 & 1.272 \\
\hline KI & $\begin{array}{l}\text { pendent Variable: } \\
\text { RJAKARYAWAN }\end{array}$ & & & & & & & \\
\hline
\end{tabular}

Source: SPSS Output, 2019

Tolerance of Communication is 0.886 , Team Work is 0.762 , and Organizational Commitment is 0.768 which means that the tolerance value of each variable is more than 0.1. The VIF value of Communication is 1.128 Team Work is 1.313 Organizational Commitment is 1.272 it means that the value of the two variables is less than 10. Because the tolerance value is more than 0.1 and VIF value is less than 10 studies are free from multicollinearity.

\section{Heteroscedasticity Result}

Scatterplot

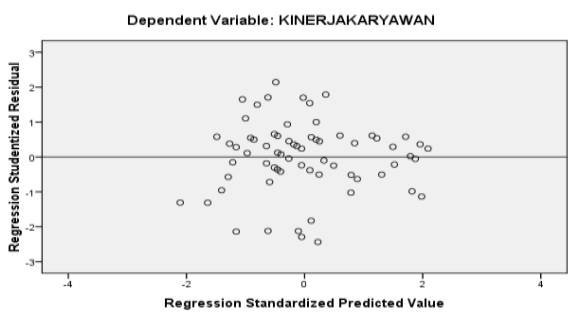

Figure 1 Heteroscedasticity Result

The pattern of dots spreads and does not make a clear pattern. The points spread above and below 0 (zero) at Y and that proves that the model is free from heteroscedasticity.

\section{Normality}

One-Sample Kolmogorov-Smirnow Test

\begin{tabular}{|ll|r|}
\hline & & $\begin{array}{r}\text { Unstandardiz } \\
\text { ed Residual }\end{array}$ \\
\hline N & Mean & 67 \\
Mormal Parameters & .0000000 \\
& Std. Deviation & .51823939 \\
& Absolute & .106 \\
Kolmogorov-Smirnov Z & Positive & .106 \\
Asymp. Sig. (2-tailed) & & -.084 \\
& & .870 \\
\hline
\end{tabular}

a. Test distribution is Normal.

Figure 2 Normality Test Result

Source : Data Processed, 2019 
In the table the results of testing the normal distribution with the Kolmogorov Smimov method to strengthen the testing with graphs obtained a significance value of $0.436>0.05$, so that the regression model is normally distributed.

\subsection{Hypothesis Testing}

1. F-Test

The F-test is used to determine all effects of all independent variables on the dependent variable. This test is done by comparing the value of $F$ count with the value of $F$ table at $\alpha=0.05$.

\begin{tabular}{|c|c|c|c|c|c|c|}
\hline \multicolumn{7}{|c|}{ ANOVA $^{\mathrm{b}}$} \\
\hline \multicolumn{2}{|c|}{ Model } & Sum of Squares & df & Mean Square & $\mathrm{F}$ & Sig. \\
\hline \multirow[t]{3}{*}{1} & Regression & 14.532 & 3 & 4.844 & 17.216 & $.000^{3}$ \\
\hline & Residual & 17.726 & 63 & .281 & & \\
\hline & Total & 32.257 & 66 & & & \\
\hline \multicolumn{7}{|c|}{ a. Predictors: (Constant), KOMITMENORGANISASI, KOMUNIKASI, KERJASAMATIM } \\
\hline \multicolumn{4}{|c|}{ b. Dependent Variable: KINERJAKARYAWAN } & & & \\
\hline
\end{tabular}

Tabel 4 Hasil Uji-F

The F-test is used to determine all effects of all independent variables on the dependent variable. This test is done by comparing the value of $F$ Count with $F$ Table value at $\alpha=0.05$. The overall effect of Communication (X1), Team Work (X2), and Organizational Commitment (X3) on employee performance (Y) is very significant.

\section{T-Test}

Table 5 T-Test Result

\begin{tabular}{|c|c|c|c|c|c|c|}
\hline \multicolumn{7}{|c|}{ Coefficients $^{\mathrm{a}}$} \\
\hline & & \multicolumn{2}{|c|}{$\begin{array}{l}\text { Unstandardized } \\
\text { Coefficients }\end{array}$} & \multirow{2}{*}{\begin{tabular}{|c|}
$\begin{array}{c}\text { Standardize } \\
\mathrm{d} \\
\text { Coefficients }\end{array}$ \\
Beta \\
\end{tabular}} & \multirow[b]{2}{*}{$\mathrm{t}$} & \multirow[b]{2}{*}{ Sig. } \\
\hline \multicolumn{2}{|c|}{ Model } & B & Std. Error & & & \\
\hline \multirow[t]{4}{*}{1} & (Constant) & 2.218 & .447 & & 1.064 & .292 \\
\hline & KOMUNIKASI & .444 & .108 & .407 & 4.097 & .000 \\
\hline & KERJASAMATIM & .253 & .107 & .254 & 2.374 & .021 \\
\hline & $\begin{array}{l}\text { KOMITMENORGA } \\
\text { NISASI }\end{array}$ & .230 & .104 & .234 & 2.223 & .030 \\
\hline & endent Variable: KIN & AKARY & CAWAN & & & \\
\hline
\end{tabular}

Source: SPSS Output, 2019

1. Table 5 shows that the hypothesis is rejecting $\mathrm{H} 0$ and accepting Ha if tcount $\geq \mathrm{t}$ table or accepting H0 and rejecting Ha if tcount $\geq t$ table. In Table 5, the communication tcount (X1) is 4.097. Comparing tcount with ttable: $4.097 \geq 1.997$. Because tcount is greater than table, $\mathrm{H} 0$ is rejected and $\mathrm{H} 2$ is accepted. Therefore Communication has a significant influence on Employee Performance.

2. Table 5 shows that the hypothesis is to reject $\mathrm{H} 0$ and accept $\mathrm{Ha}$ if tcount $\geq \mathrm{t}$ table or accept $\mathrm{H} 0$ and reject $\mathrm{H} 3$ if tcount $\geq$ ttable. In Table 5, the number of Team Work (X2) is 2.374. Comparing thitung to $\mathrm{t}$ table: $2.374 \geq 1.997$. Because $\mathrm{t}$ count is greater than $\mathrm{t}$ table, H0 is rejected and $\mathrm{Ha}$ is accepted. Therefore, Team Work has a significant influence on Employee Performance.

3. Table 5 shows that the hypothesis is to reject $\mathrm{H} 0$ and accept $\mathrm{Ha}$ if tcount $\geq \mathrm{t}$ table or accept $\mathrm{H} 0$ and reject $\mathrm{H} 3$ if tcount $\geq$ ttable. In Table 5, the number of Organizational Commitments (X3) is 2.223. Comparing tcount to $t$ table: $2.223 \geq 1.997$. Because $t$ count is greater than table, $\mathrm{H} 0$ is rejected and $\mathrm{Ha}$ is accepted. Therefore, Organizational Commitment has a significant influence on Employee Performance.

\section{Discussion}

The fourth hypothesis states that Communication, Team Work, and Organizational Commitment have a significant effect on performance. This is evident from the results of the questionnaire, the respondents stated that the company had provided give Communication, Team Work and Organizational Commitment to them. 


\subsection{Communication on Employee Performance}

The first hypothesis proposed states that communication has a significant effect on employee performance, partially this has been proven by the results of t test value 4.097. This is rational because it is in accordance with the responses of respondents regarding Communication. In response, respondents stated that the communication provided by the company was in accordance with their expectations.

\subsection{Team Work on Employee Performance}

The second hypothesis proposed states that Team Work has a significant effect on performance, partially this has been proven by the value of $t$ test results of 2.374. This is rational because it is in accordance with the respondent's response regarding Team Work. In its response the respondents stated that the Team Work carried out by the company was able to guarantee the spirit of work for employees.

\subsection{Organizational Commitment to Employee Performance}

The third hypothesis proposed states that Organizational Commitment has a significant effect on performance, partially this has been proven by the results of t test value 2.223 . This is rational because it is in accordance with the responses of respondents regarding Organizational Commitment. In his response the respondents stated that the Organizational Commitment carried out by the company was able to guarantee the comfort and tranquility of working for employees.

\section{CONCLUSION AND RECOMMENDATION}

\subsection{Conclusion}

Based on the results of the research and analysis that has been done can be raised several things which are the conclusions of this study, that are:

1. Communication (X1) has a positive and significant effect on employee performance, this means that if communication increases it will improve employee performance.

2. Team Work (X2) has a positive and significant effect on employee performance, this means that if Team Work increases it will improve employee performance

3. Organizational Commitment (X3) has a positive and significant effect on employee performance, this means that if Organizational Commitment increases it will improve employee performance.

4. Together, the three independent variables consisting of Communication (X1), Team Work (X2), and Organizational Commitment (X3) have a positive and significant influence on employee performance (Y). This means that if Communication, Team Work and Organizational Commitment increase together it will improve employee performance.

\subsection{Recommendation}

Based on the results of the research and conclusions above, the researcher needs to provide suggestions as follows:

1. Communication is proven to have an effect on employee performance, so the company should maintain good communication between employees and superiors with good communication so that employee performance will also increase.

2. The company should hold an event to retain team work such as a family gathering so that it will build a more solid team work.

3. Companies should also pay attention to Organizational Commitments because with Organizational Commitment employee performance will also increase by itself so that productivity also increases.

\section{REFERENCES}

[1] Sentngono, Hrd Syariah Teori dan Implementasi. 2014.

[2] 2009: 6 Karlfried Knapp, Pengantar Teori \& Manajemen Komunikasi. .

[3] Bachtiar, "Pengaruh Budaya Organisasi dan Gaya Kepemimpinan Terhadap Kerjasama Tim," J. Adm. Bisnis, vol. 37, p. 7, 2004.

[4] Luthans, "Pengaruh Komitmen Organisasional dan Budaya Oorganisasi Terhadap Kinerja Guru Dimediasi Kepuasan Kerja (Studi Kasus Pada Guru SMA Kesatrian dalam Yayasan Pendidikan Kesatrian 67)," 2006.

[5] Bohlander dan Snell, "Pengaruh Komunikasi, Kerjasama Kelompok dan Kreativitas Terhadap Kinerja Karyawan pada Hotel Aryaduta Manado," p. 4, 2010. 
[6] Muhammad, "Pengaruh Komunikasi Interpersonal Terhadap Kinerja Pegawai Pada Fakultas Ekonomi Universitas PGRI Palembang,” J. Media Wahana Ekon., vol. 10, p. 6, 2011.

[7] D. (2007:152), "Pengaruh Kompensasi , Kerjasama Tim Dan Kepuasan Kerja Terhadap Kinerja Karyawan Pada Ajb Bumiputera 1912 Cabang Sam Ratulangi,” vol. 5, no. 2, pp. 3018-3027, 2017.

[8] Robbins, "Analisis Pengaruh Komitmen Organisasi Terhadap Kinerja Karyawan (Studi pada Pegawai Perum Perumnas Jakarta)," 2008.

[9] Hasibuan, "Pengaruh Disiplin Kerja dan Lingkungan Kerja Terhadap Kinerja Karyawan Bagian Produksi PT. Nafal Tiara Abadi Pekanbaru," vol. 1, p. 93, 2003.

[10] Amanda Carolina Lakoy, "Pengaruh Komunikasi, Kerjasama Kelompok dan Kreativitas Terhadap Kinerja Karyawan pada Hotel Aryaduta Manado,” J. Emba, vol. 3, 2015.

[11] A. E. dan M. F. Y. Mustafa Zincirkiran, "Analysis of Teamwork, Organizational Commitment and Organizational Performance: A Study of Health Sector in Turkey,” Asian J. Bus. Manag., vol. 3, 2015.

[12] Salim Musabah Bakhit Al Zefeiti dan Noor Azmi Mohamad, "The Influence of Organizational Commitment on Omani Public Employees' Work Performance,’ Int. Rev. Manag. Mark., vol. 7, 2017.

[13] 2013:184 Sugiyono, "PENGARUH LINGKUNGAN KERJA, KOMUNIKASI INTERNAL, DAN KERJASAMA TIM TERHADAP KINERJA PEGAWAI DI DINAS KEHUTANAN PROVINSI KEPULAUAN BANGKA BELITUNG," 2017.

[14] Imam Ghozali, "Pengaruh Lingkungan Kerja, Komunikasi Internal, dan Kerjasama Tim Terhadap Kinerja Pegawai di Dinas Kehutana Provinsi Kepulauan Bangka Belitung,” p. 52, 2013.

[15] Ghozali, "Pengaruh Lingkungan Kerja, Komunikasi Internal, dan Kerjasama Tim Terhadap Kinerja Pegawai di Dinas Kehutana Provinsi Kepulauan Bangka Belitung,” p. 53, 2013.

[16] Sugiyono, "Pengaruh Lingkungan Kerja, Komunikasi Internal, dan Kerjasama Tim Terhadap Kinerja Pegawai di Dinas Kehutana Provinsi Kepulauan Bangka Belitung,” p. 64, 2013. 